Нашим учителям і колегам-будівельникам присвячується

\title{
ЕФЕКТИВНЕ БУДІВНИЦТВО НА ОСНОВІ СИСТЕМ МЕНЕДЖМЕНТУ ЯКОСТІ ТА ІННОВАЦІЙНИХ НАУКОВОМІСТКИХ ТЕХНОЛОГІЙ
}

\author{
Савенко В. I., Кущенко I. В.
}

\section{ВСТУП}

Для успішної діяльності будівельної організації дуже важливо мати замовлення, а для цього треба забезпечити конкурентоспроможність продукції на ринку й знайти свого споживача. Це можна зробити, вдосконаливши менеджмент організації та впровадивши на підприємстві сертифіковану відповідно до ISO 9001-2015 систему управління якістю, а ще краще розвинути іiі до рівня Моделі досконалості EFQM. Головним принципом такої системи є постійне вдосконалення, що стимулює пошук проблемних факторів та їх розв'язання. Енергоощадження є однією 3 найважливіших проблем у будівництві. Розв'язання цієї проблеми дозволяє організації піднятись на вищій рівень розвитку.

Зовнішні огороджувальні конструкції житлових будинків ще недавно не відповідали нормативним вимогам Свропейського рівня по енергозбереженню та були причиною багатьох негараздів. Узимку стіни промерзали, а температура всередині квартир знижувалась до $13-15{ }^{\circ} \mathrm{C}$, стики в панельних будинках затікали під час дощів, це призводило до утворення плісняви на стінах, появи грибків, відшарування шпалер, почорніння поверхні.

Заходи, які приймаються для усунення цього дефекту, а саме потовщення стін, застосування прокладок у середині стінових панелей, не дають належного результату. Не забезпечується привабливість і конкурентоздатність продукції.

3 метою відродження та розвитку будівельної галузі, підвищення якості продукції та попиту на неї необхідно таким чином організувати будівельне виробництво й управління ним, щоб інвестор був зацікавлений у вкладенні коштів саме в цю продукцію, тим самим забезпечивши джерело фінансування та розвитку виробництва.

Аналіз розроблених систем управління якістю в будівельних організаціях АТ ХК «Київміськбуд» показав, що в ряді випадків 
система документів підприємства у сфері якості й менеджменту в цілому не ефективна, не актуалізована, недостатньо пророблена, не відбиває вимог споживачів продукції, містить загальні й неконкретні формулювання, непов'язана 3 іншими елементами управління підприємством. Ці й інші недоліки призводили до того, що система менеджменту підприємства не відповідала очікуванням споживачів, відбувалося зниження конкурентоспроможності продукції та втрата підприємством своїх позицій на ринку. Позитивний у цьому плані напрацьований досвід роботи АТ ХК «Київміськбуд» і колишнього BAT «ДБК-3» і ПАТ «ДБК-4», який, на жаль, швидко забувається. Змінились власники й форми організації, оргструктури й, великою мірою, спосіб виробництва й економічна формація. Набрали чинності ринкові капіталістичні відносини. Проте менеджмент якості й міжнародні стандарти діють незалежно від форм власності, оскільки акцентують увагу на інтересах споживачів, усіх зацікавлених сторін і суспільства. 3'являються нові інноваційні технології та форми організації будівництва й реалізації продукції.

Метою дослідження $є$ популяризація позитивного досвіду в управлінні якістю продукції і іiі інвестиційною привабливістю, конкурентоздатністю за допомогою раціонального менеджменту, інноваційних технологій і наукових підходів для підвищення якості й комфортності житла.

\section{1. Менеджмент якості й ефективність діяльності організації}

Дуже важливо надати науково-методичну допомогу фахівцям у частині розробки й впровадження системи управління якістю згідно 3 міжнародними стандартами ISO 9000-2015 ${ }^{1}$, сертифікувати iii i, вдосконалюючи, довести до рівня Європейської моделі ${ }^{2}$.

Навчання та підготовка персоналу проводилась в Українській асоціації якості (Президент П.Я. Калита). Підготовка й сертифікація персоналу й систем управління якістю (далі - СУЯ) проводиться й натепер на вищому рівні не тільки у виробничих підрозділах, а навіть у провідних профільних вищих навчальних закладах ${ }^{3}$ Наприклад, у

${ }^{1}$ Савенко В.І., Клюєва В.В, Пальчик С.П. Розвиток виробничої організації на основі впровадження системи управління якістю та енергоефективних науковомістких технологій. Збірник наукових праць 7-ої міжнар. наук.-прак. конф. КЗЯТПС ЧПНУ, м. Чернигів, травень 2017 р. Чернігів, 2017. С. 102-104.

${ }^{2}$ Калита П.Я. Головна ланка, або як витягнути ланцюг соціально-економічних проблем (на прикладі України). Стандарти і якість. 2010. № 1. С. 8-13. URL: http://www.efqm.org/the-efqm-excellence-model95 (дата звернення: 20.09.2011).

${ }_{3}^{3}$ Калита П.Я. Нарис про геном успішності організацій і держави. Частина 1. Стандартизація, сертифікація, якість. 2014. № 1. С. 33-38. 
КНУБА, де завжди готували висококваліфікованих спеціалістівінженерів, науковців.

Розробка й впровадження перших систем велись на базі ВАТ «ДБК-З» АТ ХК «Київміськбуд» за Президенства В.А. Поляченка й кураторакерівника управління інспекційного контролю якості АТ ХК «Київміськбуд» А.Г. Массалова ${ }^{4}$. Після ВАТ «ДБК-3» всі підрозділи Київміськбуду були сертифіковані, що ще довгі роки, навіть після смерті цих поважних людей, підтримувало й підтримує високий імідж і бренд Київміськбуду, незважаючи на незаслужене приниження будівельників останнім часом. Розроблена й впроваджена система управління якістю ВАТ «ДБК-3» унікальна, вона об'єднувала в єдину систему процесів завод ЗБВ, управління виробничо-технологічної комплектації УВТК, три будівельно-монтажних управління БМУ - 1, 2 й 4 - й управління ВАТ «ДБК-3».Система документів СУЯ (18 настанов, 28 процедур, Політика й цілі, Місія підприємства, Комплексний план, Схема процесів і так далі) та iii впровадження дозволили підприємству стати $3^{\mathrm{x}}$ - кратним лауреатом національних конкурсів 3 якості й фіналістом міжнародного турніру 3 якості, отримати Платинову Зірку (США) за високу якість та успіхи в бізнесі, досягнувши 450-500 балів за шкалою моделі досконалості ЄФУя. ${ }^{5}$ Це далеко не найвищий міжнародний рівень, але в Україні в будівельників вищих досягнень ще не було. Не існує вже «ДБК-3», інші власники повністю демонтували оргструктуру й спосіб виробництва на капіталістичний лад, по принципу «максимальні прибутки власникам, персоналу й суспільству мінімум». Держава й інституційні органи, на жаль, не захищають інтереси персоналу й суспільства, бо реальні власники сидять у найвищих державних органах влади й творять закони під себе. Нині система менеджменту якості зруйнована, в багатьох приватних компаніях ця функція покладена на технагляд і лінійних ITП і працює (хоча це не відповідає духу й букві міжнародних стандартів і прав людини). $€$ інші форми менеджменту ${ }^{6}$, але єдиної системи немає. Тому дуже важливо зберегти накопичений цінний досвід для прийдешніх поколінь. Прикладом може служити корпорація ДБК «Житлобуд» на

${ }^{4}$ Менеджмент якості в будівництві і геном ділової досконалості організації : монографія / В.І. Савенко, С.І. Доценко, С.П. Пальчик, П.Я. Калита та ін. ; за ред. В.І Савенка. Київ : Центр учбової літератури, 2018. 230 с.

${ }^{5}$ Менеджмент якості в будівництві і геном ділової досконалості організації : монографія / В.І. Савенко, С.І. Доценко, С.П. Пальчик, П.Я. Калита та ін. ; за ред. В.I Савенка. Київ : Центр учбової літератури, 2018. 230 с.

${ }^{6}$ Савенко В.І., Доценко С.І., Клюєва В.В., Пальчик С.П. Концептуальні засади ефективного розвитку будівельної організації на базі раціонального управління. Управління розвитком складних систем : збірник наукових праць. № 33. Київ : КНУБА, 2018. С. 123-129. 
основі «ДБК-4», очолювана Героєм України П.С. Шилюком. На підприємстві успішно функціонує і розвивається система, яка забезпечує високу культуру виробництва та якість продукції.

Керуючись основними принципами міжнародного стандарту чинного в Україні ДСТУ, ISO 9001-2015 «Системи управління якістю», такими, як орієнтація на споживача, системний і процесний підхід до управління, залучення всього персоналу, прийняття рішень на основі певних фактів і постійне вдосконалення, організація може виявити слабкі й сильні сторони у своїй діяльності, поставити цілі й задачі й, мобілізувавши всі ресурси, шляхом реінжинірингу розв'язати питання підвищення конкурентоздатності підприємства. ${ }^{7}$ Вдосконалення енергоефективності - одна 3 найважливіших проблем, розв'язання якої дозволяє організації піднятись на якісно новий, вищий рівень виробництва. Наукові методи допомагають у системному підході до проблеми та іï комплексному розв'язанні шляхом теоретичних розробок $^{8}$, проведенні натурних експериментів і досліджень, розробці проєктної та нормативної документації та широкомасштабному впровадженні в будівельне виробництво 9

I хоч правильно кажуть, що впровадження та освоєння найдосконаліших, найновіших моделей - це слідування за лідером, але щоб стати лідером, треба піднятися вище за допомогою наукових та інноваційних підходів. Проте спершу треба вчитися та успішно проходити школу майстерності. Тому перші кроки переходу від хаосу телеономічного рівня виживання до вищих рівнів розвитку - це приведення та сертифікація своєї діяльності до рівня міжнародних стандартів $^{10}$. Наступний крок - це освоєння Моделі досконалості ${ }^{11}$. Для цього лідерам підприємства й усьому персоналу не формально, а на практиці необхідно навчитись регулярно проводити самооцінку,

${ }^{7}$ Менеджмент якості в будівництві і геном ділової досконалості організації : монографія / В.І. Савенко, С.І. Доценко, С.П. Пальчик, П.Я. Калита та ін. ; за ред. В.I Савенка. Київ : Центр учбової літератури, 2018. 230 с.

8 Богданов О.О. Тектологія.Загальна організаційна наука. Третє видання. Москва, 1929. С. 657.

9 Савенко B.I., Доценко С.I., Пальчик С.П., Клюєва В.В., Терещук М.О. Інтелектуальні інформаційні інструменти розвитку виробничої системи енергетичного менеджменту та підприємства в цілому. Управління розвитком складних систем : збірник наукових праць. № 37. Київ : КНУБА, 2019. С. 195-204.

${ }_{10}$ Менеджмент якості в будівництві і геном ділової досконалості організації : монографія / В.І. Савенко, С.І. Доценко, С.П. Пальчик, П.Я. Калита та ін. ; за ред. В.І Савенка. Київ : Центр учбової літератури, 2018. 230 с.

${ }_{11}$ Менеджмент якості в будівництві і геном ділової досконалості організації : монографія / В.І. Савенко, С.І. Доценко, С.П. Пальчик, П.Я. Калита та ін. ; за ред. В.І Савенка. Київ : Центр учбової літератури, 2018. 230 с. 
користуючись Логікою RADAR, а далі вступає в дію мистецтво мистецтво менеджменту ${ }^{12}$ (те, що дається від Бога за великі труди чи заслуги), наука й інновації у вигляді наукових відкриттів та ефективне швидке їх використання шляхом винаходів та інноваційних технологій, програм, проєктів. ${ }^{13}$ Але все лежить на вершині досконалості, на цілеспрямованому рівні, на освоєнні суті науки Моделі досконалості на практиці, на власному досвіді14. Це по суті нескладні речі для розуміння та осмислення. Але якби-то їх знали наші лідери на всіх рівнях, зрозуміли, оцінили й сприйняли, тоді може б Господь допоміг би їм впровадити. Отоді б... ${ }^{15}$

\section{1. Загальні принципи оцінювання підприсмства за моделлю досконалості ЕFQM}

\subsection{1. Загальна схема оцінювання}

Оцінювання подання підприємства починається 3 оцінювання окремих підкритеріїв. Підкритерії оцінюються за шкалою від 0 до 100 (у відсотках до найкращого значення). Для кожного 3 критеріїв $\mathrm{i}$ підкритеріїв, у залежності від їхньої важливості, встановлено їхню відносну частку в загальній оцінці підприємства. Згідно із цим, на основі оцінок підкритеріїв визначається загальна оцінка підприємства (за шкалою від 0 до 1000 балів). Окрім оцінки, для кожного 3 підкритеріїв формуються переліки сильних сторін та областей можливого вдосконалення. На кращі підприємства за результатами оцінки здійснюються візити з метою перевірки інформації, наведеної в поданні, визначення загального рівня підприємства, уточнення незрозумілих моментів з подання. Перед проведенням такого візиту розробляється його детальна програма ${ }^{16}$. Оцінюючи підприємство, треба враховувати такі базові принципи:

${ }^{12}$ Мільнер Б.3. Теорія організації : підручник. Москва : Вища освіта, 2005. 646 с.

13 Дослідження i математичне моделювання організаційних структур та виробничих процесів будівельних організацій комбінатного типу : монографія / В.І. Савенко, С.І. Доценко, І.С. Нестеренко, П.М. Куліков та ін. ; за ред. В.І. Савенка. Київ : Центр учбової літератури, 2018. 124 с.

14 Савенко B.I., Доценко C.I., Пальчик С.П., Клюєва В.В., Терещук М.О. Інтелектуальні інформаційні інструменти розвитку виробничої системи енергетичного менеджменту та підприємства в цілому. Управління розвитком складних систем : збірник наукових праць. № 37. Київ : КНУБА, 2019. С. 195-204.

15 Научно-технические основы энергоэффективного экологически чистого электроотопления помещений, энергосбережение и энергоменеджмента: монография / І.В. Савенко, Н.М. Фіалко, С.І. Доценко, П.М. Куліков ; за ред. Н.М. Фіалко. Київ : Центр учбової літератури, 2018. 371с.

16 Калита П.Я. Нарис про геном успішності організацій і держави. Ч. 1. Стандартизачія, сертифікаичія, якість. 2014. № 1. С. 33-38. 
1. Під час оцінювання може враховуватися тільки інформація, чітко й недвозначно викладена в поданні. Не повинна братися до уваги, будьяка інформація про підприємство, якою попередньо володів експерт.

2. Експерт повинен довіряти інформації, викладеній у поданні, вважати ії вірною. Докази, що підтверджують інформацію з подання, можуть бути перевірені під час візиту на підприємство.

3. Під час оцінки матеріалів подання повинні враховуватися об'єктивні факти, які можуть бути перевірені під час візиту на підприємство. Не впливають на оцінку емоціональні твердження, літературний стиль тощо.

4. Мало впливають або не впливають на оцінку описи діяльності підприємства, які є обов'язковими відповідно до чинного законодавства.

5. Оцінюючи подання, треба брати до уваги розміри підприємства, галузь тощо. Від підприємства, на якому працюють 300 осіб, не можна чекати такої ж діяльності, як і від того, на якому працюють 10000.

6. Якщо текст подання за певним підкритерієм містить посилання на інший підкритерій, експерт повинен перевірити й врахувати інформацію, викладену в іншому підкритерії. Також під час оцінювання підкритерію можна використовувати інформацію з інших підкритеріїв (принаймні, в межах одного критерію) навіть без посилання.

7. Повинна враховуватися тільки та інформація, що безпосередньо стосується відповідного підкритерію. Навіть цінна інформація, яка характеризує досконалість підприємства, але не пов'язана 3 відповідним підкритерієм, не впливає на його оцінку.

8. Експерти повинні дотримуватися правил конфіденційності, забезпечити зберігання та нерозповсюдження інформації, викладеної в поданні.

\subsection{2. Оріснтовна шкала оцінок підприсмств}

Хоча максимальна можлива оцінка для підприємства й складає 1000 балів, жодне 3 реальних підприємств не наблизилося до цієї оцінки. Під час оцінювання підприємства можна брати до уваги такі «точки відліку»: 200 балів - рівень середнього європейського підприємства; 300 балів - наявні ознаки елементів загального управління якістю на підприємстві, використання «нетривіальних» підходів; 400 балів - рівень підприємств-лідерів на національному рівні; 500 балів - на підприємство здійснюється візит (за правилами Європейської нагороди 3 якості); 550 балів - підприємство - фіналіст Свропейської нагороди 3 якості; 600-650 балів - підприємство володар Свропейського призу з якості; 700-750 балів - підприємство володар Європейської нагороди 3 якості. Оцінюючи підприємства, доцільно порівнювати їхню оцінку із цією шкалою.

\section{2. Матричний підхід до оцінювання підприємств}

Відповідно до практики, прийнятої під час проведення Європейської нагороди 3 якості, оцінювання підприємств здійснюється 
за допомогою спеціальних матриць. Подібні матриці заповнюються для кожного 3 підкритеріїв. Такий підхід дозволяє всебічно врахувати всі складові частини подання підприємства й формалізувати процеси оцінювання. ${ }^{17}$ Матричний підхід грунтується на тому, що спершу за визначеною шкалою оцінюють різні складові частини підкритерію. Оцінка критеріїв можливостей складається з оцінок:

1) підходу;

2) застосування підходу;

3) оцінки й перегляду підходу.

Оцінка підходу складається 3 оцінки його обгрунтованості й інтегрованості. Оцінка перегляду підходу складається 3 оцінки його вимірювання, навчання та удосконалення. Оцінка рівня результатів своєю чергою складається з оцінки тенденції, порівнянь із внутрішніми планами, порівнянь із зовнішніми організаціями, покликаних підходами. Оцінка кожної зі складових частин відзначається у відповідній матриці. Після цього для підкритеріїв можливостей визначається оцінка підходу (як середня між оцінками обгрунтованості й інтегрованості), оцінка застосування (як середня між оцінками систематичності й впровадження), оцінка перегляду (як середня між оцінками вимірювання, навчання та удосконалення). Далі визначається загальна оцінка підкритерію як середня між оцінками підходу, застосування та перегляду. Середня оцінка не обов'язково повинна збігатися із середнім арифметичним оцінок складових частин. Оцінка може дещо зменшуватися або збільшуватися в порівнянні 3 арифметичним середнім для найточнішого відбиття загального враження експерта від підприємства. Особливо при великій різниці між значеннями оцінок складових частин загальна оцінка може бути суттєво зменшена. У будь-якому випадку, на всіх етапах оцінювання оцінка повинна бути кратною 5 (точність експертного підходу до оцінювання). Оцінка підприємства за підкритеріями результатів визначається схемою.

\section{EFQM \\ 1.3. Оцінка окремих складових підкритеріїв моделі досконалості}

1.3.1. Критерї̈ можливостей ${ }^{18}$

У критеріях можливостей експерти повинні насамперед шукати чіткі докази того, що діяльність ефективна. Для цього потрібна детальна інформація про те, як виконується діяльність, про процедури

17 Калита П.Я. Нарис про геном успішності організацій і держави. Ч. 1. Стандартизація, сертифікація, якість. 2014. № 1. С. 33-38.

${ }^{18}$ Калита П.Я. Головна ланка, або як витягнути ланцюг соціально-економічних проблем (на прикладі України). Стандарти і якість. 2010. № 1. С. 8-13. URL: http://www.efqm.org/the-efqm-excellence-model95 (дата звернення: 20.09.2011). 
iii виконання. Ця інформація повинна бути подана у формі, яка б дозволяла перевірити іiі правдивість під час візиту на підприємство. У моделі використовуються посилання на такі категорії доказів:

1) необгрунтовані докази;

2) деякі докази;

3) докази;

4) чіткі докази;

5) виняткові докази.

«Необгрунтовані докази» - це загальні твердження без будь-яких пояснювальних фактів. Наприклад, «Керівництво підприємства приділяє велику увагу встановленню партнерських стосунків зі споживачами». Можливо, це твердження відповідає дійсності, але 3 нього не можна зробити висновків, як керівники приділяють увагу встановленню партнерських стосунків зі споживачами, а отже, не можна реально оцінити, наскільки підходи ефективні й сприяють досягненню підприємством позитивних результатів. «Деякі докази» вимагають, щоб були зрозумілі підходи, які використовуються підприємством, навіть якщо вони не цілісні або не ефективні. «Докази» вимагають наявності формальної процедури діяльності, за якою можна було б чітко оцінити іiі ефективність. За описом повинно бути зрозуміло, що йдеться про цілісний підхід, а не про сукупність окремих ініціатив. «Чіткі докази» стосуються детального опису того, яким чином реалізується підхід у рамках певного підкритерію, як він відповідає основним концепціям TQM, проілюстрованого прикладами, з посиланнями на спеціальні методи, що використовуються. Нижче наведені зауваження щодо оцінювання окремих складових частин критеріїв можливостей:

\subsection{2. Обтрунтованість}

Увага повинна приділятися не тільки тому, які підходи застосовуються, але й тому, як вони використовуються, як і чому були обрані (наприклад, за підсумками досліджень, опитувань, вивчення досвіду інших організацій). Особливо важливо знайти докази зв'язку між обраними підходами й потребами всіх зацікавлених сторін. Це $\epsilon$ обов'язковою умовою для оцінок 50-60\%.

\subsection{3. Інтегрованість}

Для отримання високої оцінки за цією складовою частиною підприємство повинно надати докази спрямованості обраних підходів на реалізацію загальної стратегії, проілюструвати чіткий зв'язок між ними.

\subsection{4. Систематичність}

У рамках цієї складової частини оцінюється, як методично побудовано запровадження нових підходів. Для отримання високої оцінки необхідні посилання на відповідний план чи проєкт із впровадження. 


\subsection{5. Упровадження}

Оцінюється поширення впровадженого підходу на різні підрозділи, рівні управління, категорії персоналу, споживачів, продукції тощо. Необхідно шукати в матеріалах подання такі слова, як «усі споживачі», «кожен підрозділ», «30\% персоналу» тощо. Якщо різні складові частини підходу мають різні області впровадження, оцінюється середній рівень для них.

\subsection{6. Вимірювання}

У цій складовій частині оцінюються не стільки результати вимірювання підходів, скільки процес вимірювання (механізми, відповідальність за їх використання, періодичність). Схема вимірювання повинна бути досить широкою для того, щоб оцінювати ефективність підходів і рівень їхнього впровадження. Для отримання високої оцінки підприємство повинно обгрунтувати вибір різних видів вимірювання та періодичність їхнього застосування, а також чітко проілюструвати їхній зв'язок із різними критеріями результатів.

\subsection{7. Навчання}

У цій складовій частині оцінюється те, як побудовано процеси виділення кращої практики за відповідним підкритерієм як на самому підприємстві, так і за його межами, проведення досліджень у цій галузі тощо. Для отримання високої оцінки підприємство повинно надати певні пояснення стосовно вибору певних методів навчання.

\subsection{8. Удосконалення}

У цій складовій частині оцінюються механізми визначення областей можливого удосконалення, визначення їх пріоритетів і планування подальших дій у рамках відповідного підкритерію. Повинно бути зрозуміло, як для цього використовується інформація, зібрана за підсумками вимірювання та удосконалення.

\section{4. Критерії результатів}

Важливим моментом під час оцінки критеріїв результатів $є$ визначення, що таке «деякі результати», «багато результатів», «більшість результатів». Ці значення залежать від загальної кількості наведених показників. Так, якщо в підкритерії наведено 10 показників, то:

1) «деякі результати» означає 1, 2 чи 3 показники;

2) «багато результатів» означає 4, 5 чи 6 показників;

3) «більшість результатів» означає понад 7 показників.

Якщо в підкритерії наведено 6 показників, то:

1) «деякі результати» означає 1 чи 2 показники;

2) «багато результатів» означає 3 чи 4 показники;

3) «більшість результатів» означає 5 показників.

Тенденції в матриці оцінювання використовують означення «позитивні» й «сильно позитивні». Прикладом «позитивні тенденції» може бути така: 7, 10, 9, 13, 12, 15. Хоча загальна позитивна тенденція i прослідковується, допускаються локальні погіршення показника. Для 
«сильно позитивної» тенденції обов'язковим є покращення показника за кожен період вимірювань. У певних випадках допускається висока оцінка тенденції, навіть якщо значення показника постійне й не покращується. Але в цьому випадку підприємство повинно надати чіткі докази того, що показник дійсно не може більше покращуватися або його зростання недоцільне. Взагалі, підприємство може в багатьох випадках аргументувати, що негативні тенденції чи порівняння викликані незалежними від них причинами. Експерт повинен прискіпливо вивчити аргументацію підприємства, щоб вирішити, чи брати його до уваги. Наприклад, пояснення негативної тенденції показника загальною економічною кризою не може бути прийняте, якщо інші підприємства галузі покращують цей показник.

\subsection{1. Порівняння з планами}

Оцінюючи цю складову частину, треба брати до уваги, що позитивне порівняння досягнутих результатів із плановими значеннями означає виконання планів або їх незначне перевищення. Значне перевиконання планів викликає сумніви в ефективності процесу встановлення цілей, особливо якщо план на наступний період поступається фактичному значенню за попередній. У будь-якому випадку, для отримання високої оцінки за цією складовою частиною підприємство повинно надати пояснення щодо того, як встановлюються планові значення, а також проілюструвати позитивні порівняння не тільки за останній період, але й за кілька років.

\subsection{2. Порівняння із зовнішніми організаціями}

Під час оцінювання зовнішніх порівнянь важливо враховувати вибір організації для порівняння. Позитивні порівняння 3 гіршими організаціями галузей не можуть суттєво підвищувати оцінку, тому підприємство повинно кожен раз аргументувати свій вибір. Для отримання оцінки на рівні $50-60 \%$ підприємство повинно надати позитивні порівняння із середнім рівнем по галузі або з іiі явними лідерами, для оцінки 75-80\% - із рівнем кращої організації свого класу.

\subsection{3. Результати, викликані підходами}

Для отримання високої оцінки за цією складовою частиною підприємство повинно не обмежуватися загальним посиланням «високі результати викликані досконалими підходами». Повинні бути надані докази проведення аналізу «причина - наслідок», наведені конкретні приклади зв'язку між покращенням результатів та удосконаленням окремих підходів, між позитивними зовнішніми порівняннями й використанням унікальних підходів.

\subsection{4. Діапазон результатів}

Під час оцінки діапазону результатів насамперед враховується кількість наведених показників. Але для отримання досить високої оцінки ці показники повинні охоплювати всі можливі аспекти 
відповідних результатів, давати цілісну картину досягнень підприємства. Важливо оцінити обгрунтованість вибору наведених показників, особливо для критеріїв 6, 7 і 8, повинні бути надані докази того, що ці показники матимуть змогу характеризувати основні потреби відповідних зацікавлених сторін. Відносна важливість показників повинна враховуватися й під час оцінювання тенденції, порівнянь із внутрішніми планами чи зовнішніми організаціями.

\section{5. Опис сильних сторін підприємства й областей можливого вдосконалення ${ }^{19}$}

За підсумками оцінювання підприємствам-учасникам конкурсу надається перелік сильних сторін та областей для вдосконалення за кожним із підкритеріїв. Ця інформація повинна допомогти підприємствам краще зрозуміти наведені оцінки й визначити можливі шляхи вдосконалення власної діяльності. Кількість сильних сторін та областей для удосконалення за кожним із підприємств повинна бути узгодженою 3 його оцінкою. Як правило, за кожним із підкритеріїв може наводитися 5-6 тверджень про сильні сторони й області для вдосконалення. Водночас бажано мати на увазі, що інформація про області для вдосконалення корисніша для підприємств, тому кількість такої інформації можна робити дещо більшою. Кількість сильних сторін та областей для удосконалення повинна бути узгодженою з оцінкою відповідного підкритерію (чим вища оцінка - тим більше сильних сторін і менше областей для удосконалення). За певним підкритерієм може бути не наведено жодної його сильної сторони (області для удосконалення) лише в тому випадку, якщо його оцінка складає 0 відсотків (100 відсотків). Основні принципи, яких треба дотримуватися під час опису сильних сторін та областей для вдосконалення:

1) бути тактовними. Уникати різкої та неконструктивної критики. Не піддавати сумніву інформацію, наведену в поданні;

2) наводити твердження в порядку важливості. Відбирати тільки важливу інформацію;

3) переважно вживати слова й поняття, які використовуються підприємством у поданні;

4) писати коментарі до підкритеріїв чіткою, зрозумілою людині, не знайомій з моделлю, мовою. Бажано застосовувати повні речення. Там, де це можливо, використовувати слова, вжиті підприємством у поданні (особливо для сильних сторін);

${ }^{19}$ Менеджмент якості в будівництві і геном ділової досконалості організації : монографія / В.I. Савенко, C.I. Доценко, С.П. Пальчик, П.Я. Калита та ін. ; за ред. В.І Савенка. Київ : Центр учбової літератури, 2018. 230 с. 
5) не змішувати роботу експерта й консультанта. Вказувати області для вдосконалення, а не рекомендувати шляхи вдосконалення. Не акцентувати увагу на власному досвіді або досвіді свого підприємства;

6) намагатися давати інформацію, яка могла б бути корисною для підприємства. Області для вдосконалення повинні обиратися таким чином, щоб розширення підкритерію відповідною інформацією позитивно впливало на його оцінку;

7) чітко пов'язувати коментарі з конкретним підкритерієм. Якщо в тексті підкритерію наведена позитивна інформація, яка не стосується цього підкритерію, вона не може розглядатися як сильна сторона;

8) бути послідовним. Одна й та сама діяльність не може бути й сильною стороною, і областю для вдосконалення (як в одному підкритерії, так і в різних).

Також треба мати на увазі, що коментарі даються тільки за текстом подання, а не за реальною діяльністю підприємства. Тому замість фраз «не проводиться діяльність...» краще вживати «відсутні докази діяльності...», «не описана діяльність...» тощо. Але, використовуючи такі фрази, треба бути абсолютно впевненим у тому, що відповідні докази дійсно повністю відсутні. Якщо в підкритерії наведена хоча б побіжна інформація про відповідну діяльність, краще писати «відсутні чіткі докази...», «відсутня інформація про те, як...». Не повинні вказуватися як сильні сторони чи області для вдосконалення окремі ініціативи або незначні питання діяльності підприємства, а також діяльність, яка $\epsilon$ звичною або обов'язковою для вітчизняних підприємств за винятком дуже невисокої оцінки за підкритерій. Як правило, основні складові частини відповідних критеріїв та основні підходи, що можуть використовуватися в їх рамках, повинні згадуватися або в сильних сторонах, або в областях для вдосконалення. Наприклад, для критеріїв можливостей може згадуватися або наявність системи вимірювання підходів, або іiі відсутність, для критеріїв результатів - або позитивні зовнішні порівняння (сильна сторона), або їх відсутність чи негативні порівняння (область для удосконалення). Так само для підкритерія $3 б$ може бути відзначена наявність або відсутність системи внутрішнього навчання, в підкритерії 6бнаявність або відсутність показників лояльності споживачів тощо. Усім експертам будуть видані типові області для удосконалення для кожного підкритерія. Але необхідно не обмежуватися типовими областями, а враховувати індивідуальні підходи підприємства, які могли б бути удосконалені ${ }^{20}$.

${ }^{20}$ Савенко B.I., Доценко С.I., Клюєва В.В., Терещук М.О. Оптимальні методи управління будівельною організацією комбінатного типу. Управління розвитком складних систем : збірник наукових праць. № 35. Київ : КНУБА, 2019. С. 147-154. 


\section{2. Інноваційні технології як складова частина загальної схеми розвитку організації. Ощадливі екоенерготехнології - основа економіки організації та держави}

Низькі ціни на паливо, які діяли в Україні до останнього часу, до розпаду СРСР, привели до того, що рівень використання енергії в нашій країні залишився вищим, ніж у країнах Західної Свропи, в той час як ефективність її використання залишилась низькою.

Раціональна витрата й економія теплової енергії в Україні за останні десятиліття стала найгострішою проблемою. 3 огляду на наявний дефіцит енергоносіїв і коштів на їхне придбання, а також екологічні наслідки нарощування споживання енергії, величезного значення набуває раціональне використання та зменшення втрат енергії.

Біля 40\% від загального використання енергії випадає на житловий сектор. Враховуючи різкий дефіцит енергоносіїв, Україна ввела нові підвищені нормативи опору теплопередачі як для нового будівництва, так і для реконструкції будівель. До середини 1995 року понад 50\% підприємств великопанельного домобудування, керуючись новими нормативами, перейшли на випуск огороджувальних конструкцій із підвищеним у 2-3 рази рівнем теплозахисту.

Роль теплозахисту будинків у підвищенні ефективності енергозбереження житлових і цивільних будинків досить значна. Нині більшість будівельних компаній України застосовують зовнішне утеплення багатоповерхових житлових будинків із встановленням віконних блоків зі склопакетами.

Фахівці «ДБК-3» разом із науковцями ІТТФ НАНУ, ДП НДІБК, ДП НДІБВ, КНУБА, ПАТ Київ ЗНДІЕП тощо понад 20 років плідно працювали над розв'язанням проблеми енергозбереження в будівництві. Проводились теоретичні, експериментальні й науководослідні роботи, спрямовані на розв'язання цієї проблеми. Так, в Україні зовнішнє утеплення під час будівництва багатоповерхівок було застосоване на ВАТ «ДБК-3» ще в 1995 році на масиві Південна Борщагівка, на житловому будинку 6 по вулиці Гмирі, на масиві Осокорки в місті Києві, а потім масово після коригування відповідних державних нормативів ${ }^{21}$.

Зараз для зовнішнього утеплення застосовується вентильований «Термофасад», який призначений як для теплоізолювання під час будівництва, так i для додаткового теплоізолювання вже наявних об'єктів, насамперед у цивільному й житловому будівництві. Ця система захищає також від спеки, бо має вентильований повітряний

${ }^{21}$ Савенко В.І., Сухоросов І.М., Полосенко О.В., Тарасов В.О., Фіалко Н.М. Енергозберігаючі технології в будівництві та система управління якістю. Будівельні матеріали, вироби та санітарна техніка. 2009. № 1 (31). С. 96-99. 
прошарок, який, ніби радіатор в автомобілі, відводить тепло з нагрітих сонцем поверхонь стін ${ }^{22}$.

Термофасад - це система, яка складається 3 таких конструкційних елементів і матеріалів:

- профільований бетонний камінь (кам'яний профіль);

- монтажний профіль;

- металева опорна конструкція - кронштейни й профілі;

- теплоізоляція (плитний утеплювач) із вітрозахистом;

- елементи кріплення;

- обшивка вікон і дверей, кутові й кінцеві профілі.

Під час влаштування вентильованого фасаду шари різних матеріалів розташовують таким чином, що в напрямку зсередини споруди назовні теплопровідність матеріалів та їх опір водяній парі зменшується (бетон чи цегла, мінераловатний утеплювач, повітряний прошарок, захисне декоративне облицювання). Таке розташування матеріалів разом із дією повітряного прошарку, де через перепад тиску відбувається постійний вертикальний рух повітря, дозволяє ефективно видаляти вологу як 3 опорної стіни, так i 3 утеплювача, що підвищує ефективність теплоізоляції будівлі й забезпечує відносно сухий стан утеплювача під час всього періоду експлуатації. ${ }^{23}$ Крім того, зменшення тепловтрат відбувається також внаслідок виникнення ефекту «повітряної теплової завіси», тому що температура вертикального теплового потоку на два-три градуси вище, ніж у зовнішнього повітря. Масивна конструкція каркасу акумулює тепло, яке зберігає зовнішній утеплюючий шар.

Влаштування теплоізоляції ззовні краще захищає стіну від перемінного замерзання та відтавання. ${ }^{24}$ Вирівнюються температурні коливання масиву стіни, що перешкоджає виникненню деформацій. особливо небажаних під час індустріального будівництва. Точка роси зміщується в зовнішній теплоізоляційний шар, внутрішня частина стіни

\footnotetext{
${ }^{22}$ Фиалко Н.М., Черных Л.Ф. Тепловое состояние трехслойных наружных стен помещения при напольном электротеплоаккумуляционном отоплении Промышленная теплотехника. Приложение к журналу. 2004. Т. 26. № 5. С. 48-56.

${ }^{23}$ Фиалко Н.М., Черных Л.Ф., Постоленко А.М. Влияние внутреннего каркаса здания на его тепловой режим. Оконные технологии. 2005. № 20-21. С. 44-47.

24 Богословский В.Н., Ферт А.Р., Черных Л.Ф. Экспериментальное подтверждение методики расчета наружных ограждающих конструкций. Теплоустойчивость наружных ограждающих конструкций зданий с учетом зависимости теплофизических характеристик от температуры. Bonросы повышения энергетической эффективности кондиционирования микроклимата. Москва : МИСИ им. В.В. Куйбышева, 1989. С. 10-14.
} 
не відвологає й не потребує додаткової пароізоляції. Іншою перевагою зовнішньої теплоізоляції є збільшення теплоакумулювальної здатності масиву стіни. Установка теплоізоляції ззовні дозволяе також виключити проблему «містків холоду» під час каркасно-монолітного будівництва.

Технічні характеристики системи:

1. Облицювальний камінь $є$ бетонним профілем «Інтерстоун», який виготовляється з бетону В20 методом напівсухого формування. Розміри: $600 \times 600 \times 30$ мм; вага: 2,94 кг; щільність: 2000 кг $/ \mathrm{M}^{3}$; міцність на згін: 600-800 Н; морозостійкість: F 35; водопоглинання: не більше 12\%; основний колір: білий, пісочний, жовтий, кремовий, бежевий, темножовтий, теракот, темно-коричневий, темно-зелений, синій.

2. Облицювальна система «Кронштейн» $є$ сталевим листом товщиною 1,5 мм або 2,0 мм (ГОСТ 1653-70). Спосіб захисту від корозії - гаряче оцинкування товщиною не менше 60 мкр або інший, що йому відповідає. Розміри: $40 \times 200 \times 65$ мм. Розрахункова монтажна схема установки: по горизонталі - 700 мм, по вертикалі - 620 мм.

Опорний профіль є сталевим листом товщиною 1,0 мм (ГОСТ 1653-70). Спосіб захисту від корозії - такий же. Розміри: 45 × 45 мм. Монтажна схема установки: горизонтально - через 620 мм.

Монтажний профіль $\epsilon$ сталевим листом товщиною 0,8 мм (ГОСТ 9045-80). Спосіб захисту від корозії - такий же. Монтажна схема установки: вертикально - через 300 мм.

3. Утеплювач - мінеральна вата з базальтового волокна товщиною 100-150 мм. Розмір листів: $625 \times 1000 \times 100$ мм. Теплопровідність при $25^{\circ} \mathrm{C}-0,040$ Вт/м ${ }^{2}$. Марки утеплювачів до 70 м висоти будівлі «PANELROCK ROCKWOOL», питома щільність 60-70 кг/ $\mathrm{M}^{2}$, понад

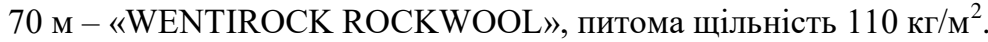

Під час використання вентильованих «Термофасадів» у панельному житловому будівництві питання, пов'язані з промерзанням, задуванням і затіканням стиків, розв'язується самим «Термофасадом», тому що він дозволяє закрити поверхню фасаду, в тому числі й стики, від атмосферних впливів.

ВАТ «ДБК-3» були проведені дослідження та розробка нового типу зовнішніх трьох шарових стінових панелей із застосуванням пінопласту й пінополістирольної спіненої стрічки. Випробування теплофізичних властивостей панелей нового типу проводились відділом будівельної теплофізики Київ ЗНДіЕП разом 3 ІТТФ $\mathrm{HAHУ}^{25}$. У результаті

${ }^{25}$ Менеджмент якості в будівництві і геном ділової досконалості організації : монографія / В.І. Савенко, С.І. Доценко, С.П. Пальчик, П.Я. Калита та ін. ; за ред. В.І Савенка. Київ : Центр учбової літератури, 2018. 230 с. 
випробувань встановлено, що середній опір теплопередачі випробувальних зразків становить $3-3,8\left(\mathrm{M}^{2}{ }^{\circ} \mathrm{C}\right) / \mathrm{BT}$ (у залежності від товщини шару утеплювача). Цей показник значно підвищує ефективність енергозбереження житлових будинків.

Проблеми, пов'язані з промерзанням чи задуванням через дерев'яні вікна «старого» житлового фонду, можна розв'язати за допомогою встановлення віконних конструкцій зі склопакетами 3 можливістю відкриття для провітрювання. Склопакет - виріб із двох або більше листів скла, герметично з'єднаних по периметру, який розташовується в каркасі, що несе механічне навантаження.

Теплоізоляційні властивості склопакета визначаються кількістю камер (однокамерний або двокамерний чи трикамерний), відстанню між склом, типом скла і його товщиною. Двокамерний склопакет із «теплим пустотним профілем» і дистанцією між склом не менше 10 мм (4-10-4-10-4) забезпечує значення коефіцієнта опору теплопередачі $0,6-0,8$ м $^{2}$ град/Вт, що вище нормативного $\left(0,6\right.$ м $^{2}$ град/Вт для такої температурної зони України).

Для того, щоб збільшити опір теплопередачі, в деяких моделях склопакетів простір між склом іноді заповнюють інертними газами: аргоном або криптоном. Теплозахисні властивості склопакетів, що заповненні інертними газами, збільшуються на 12-13\%. Теплова ефективність тришарового скління основана на знижені конвективних (15\%) і тепловтрат теплопровідністю (15\%). Але понад 70\% теплоти втрачається через скло шляхом випромінювання. Знизити променеву складову частину тепловтрат можливо шляхом нанесення на скло тепловідбивного покриття. Опір теплопередачі двокамерного склопакета складає $0,6 \mathrm{~m}^{2}$ град/Вт, а однокамерного 3 нанесенням тепловідбивного покриття - 0,6-0,7 м² град/Вт.

Звідси висновок, що вигідніше застосовувати не третє скло, а покриття, що відбиває тепло, оскільки застосування третього скла призводить до перевитрат матеріалу на віконну конструкцію, зменшення світло пропускних властивостей внаслідок третього скла, збільшенню ваги вікна. Тепловідбивальні покриття на склі володіють низьким ступенем чорноти в інфрачервоному діапазоні довжини хвиль від 2,5 до 25 мкм. Скло 3 таким покриттям на 5\% менше пропускає світла й відбиває назад у приміщення до 90\% тепла, що виходить шляхом випромінювання. В літню пору таке покриття відбиває інфрачервоні промені на вулицю, тим самим не допускається перегрів приміщення. Відомі також моделі з підігрівом скла, навіть віддачею тепла в приміщення, але поки що широкого застосування не знайшли.

Віконна рама займає $15-35 \%$ площі вікна. Тому теплотехнічні параметри віконного профілю також повинні відповідати нормативним 
вимогам. Рами виготовляють із багатокамерного профілю 3 різних матеріалів: полівінілхлориду (далі - ПВХ), дерева або металу (алюмінію). Високі теплоізоляційні властивості забезпечують 3-х камерні профілі з двома контурами зовнішнього ущільнення: один по зовнішньому периметру рами, другий - по зовнішньому периметру стулки (в приміщенні).

Коефіцієнт теплопровідності ПВХ і дерева складає 0,15-0,2 Вт/м град. Коефіцієнт теплопровідності алюмінію біля 220 Вт/м град, що в 1000 разів перевищує теплопровідність ПВХ чи дерева. Тому доцільне створення алюмінієвих конструкцій з опором теплопередачі, який буде відповідати нормативному значенню 0,45 м $^{2}$ град/Вт. Не світлопрозора частина цих конструкцій у варіанті 3 двокамерним склопакетом повинна мати опір теплопередачі не менше 0,48-0,5 м² град/Вт при великій площі скління. Таким чином, сучасні конструкції склопакетів (двокамерних чи однокамерних зі спеціальним покриттям) забезпечують необхідні теплоізоляційні властивості. Основні проблеми під час використання таких віконних конструкцій виникають під час їх монтажу в залізобетонні або цегляні огороджуючи конструкції.

Теплотехнічні властивості навіть найкращої віконної конструкції можуть бути втрачені під час не правильного iі монтажу. До теплотехнічних характеристик монтажних швів (у місці спряження віконної та будівельної конструкцій) висуваються визначені вимоги: високий опір теплопередачі, звукоізоляція, вологоперенос, фільтрація повітря, механічна міцність і можливість компенсувати теплові деформації віконної конструкції ${ }^{26}$.

Водночас механічні навантаження в зоні спряження повинні компенсуватися властивостями шва. Вибір оптимальних параметрів монтажних швів (геометричних, теплофізичних і масообмінних) завдання, яке зумовлює ефективність застосування сучасних віконних конструкцій. У такому випадку дуже важливо, щоб каркас будинку, до якого кріпляться вікна, був «теплим». Це забезпечується використанням зовнішнього утеплення.

Система зовнішнього утеплення, яку обгрунтували й випробували вчені спочатку в лабораторіях та експериментальному будівництві, нині на практиці дає позитивні результати. А робота вчених $\mathrm{i}$ спеціалістів, виконана на цю тему у 2013 році, представлена Державним комітетом НАНУ на нагороду - Державну премію України в галузі науки й техніки. Натепер наука й технічний прогрес розвиваються дуже швидко, з'являються нові ідеї, винаходи,

\footnotetext{
${ }^{26}$ Фиалко Н.М., Черных Л.Ф., Постоленко А.М. Влияние внутреннего каркаса здания на его тепловой режим. Оконные технологии. 2005. № 20-21. С. 44-47. 
відкриваються нові перспективи. ${ }^{27}$ Дуже перспективною виглядає ідея розумної рекуперації тепла в житлових будинках, висловлена відомим білоруським архітектором С.Г. Брянцевим, автором проєкту «Розумний будинок», на науково-практичній конференції в Полоцькому державному університеті (грудень 2019 року). За такими ідеями й натхненними вченими-новаторами майбутнє. I можна тільки радуватись, що їхня Вітчизна їх підтримує, заохочує до плідної творчої діяльності.

\section{ВИСНОВКИ}

Впровадження ефективного менеджменту підприємства й системи управління якістю спонукає організацію до визначення основних процесів виробництва та їхніх параметрів (розробка схеми процесів, політики, місії, цілей, постійний моніторинг та аналіз виконання 3 подальшим коригуванням і визначенням домінантних факторів, що впливають на якість продукції та її конкурентні можливості).

Головними факторами покращення якості й конкурентоздатності будівельної продукції (під час добросовісного виконання та оптимальної ціни) $є$ енергоефективність та інноваційна діяльність персоналу за підтримки держави шляхом створення сприятливих умов для продуктивної творчої праці.

На етапах розвитку систем та організацій вище телеономічного рівня тільки впровадження передових сучасних моделей, наука й наукові підходи, а не бюрократична система (яка, по суті, стає гальмом прогресу виробничих сил і відносин), може забезпечувати реальний сталий розвиток соціальних наукомістких виробничих систем, змінити на краще перспективи розвитку суспільства.

Щоб ефективно застосовувати наукомісткі моделі й інноваційні технології, керівники й персонал повинні мати відповідні здібності, освіту, кваліфікацію, підготовку й досвід, а для об'єктивної оцінки кадрів має діяти неупереджений, незалежний державний механізм підготовки й відбору кадрів.

\section{АНОТАЦІЯ}

Отримані результати багаторічних досліджень і пошуків шляхів підвищення ефективності роботи будівельних організацій через удосконалення системи управління якістю та покращення якості продукції домобудівного комбінату, підвищення енергозберігаючих властивостей огороджувальних конструкцій житлових будинків на базі

${ }^{27}$ Шаповалова І.С. Соціогенетичний підхід у вивченні організаційної культури. Наукові відомості БелГУ. 2009. № 5. С. 159-167. 
серії 111-161, комфортності житла й підвищення попиту на нього дали можливість у свій час сформувати позитивний імідж і сприятливе середовище для ведення бізнесу. Наукові відкриття та інноваційні технології дозволяють передбачити й забезпечити виконання майбутніх потреб і попиту споживачів, тим самим створити собі джерело щасливого функціонування. Зовнішні фактори можуть сприяти розвитку підприємства, але можуть і руйнувати, створюючи, свідомо чи несвідомо, несприятливі, руйнівні умови, бо інституційні державні сили значно потужніші за внутрішні системні зв'язки в оргструктурах, керівні й керовані підсистеми організації. Відомі випадки, коли підприємства повністю переходили на території інших держав, де створені сприятливі умови для виробництва й бізнесу, щоб врятуватися від розорення. Проте за нормальних умов попит на будівельну продукцію, зокрема на житло, визначають прийнятна ціна й висока якість, зручність і комфортність. Одним із найважливіших факторів $\epsilon$ теплова комфортність, яка забезпечується надійною теплоізоляцією огороджувальних конструкцій. Інноваційні технології на науковій основі якраз і дозволяють цього досягти за допомогою різних систем. У тому числі за допомогою зовнішніх утеплених фасадів, зокрема системи Термофасад, Сканрок і багатьох інших такого типу систем.

\section{ЛIТЕРАТУРА}

1. Савенко В.І., Клюєва В.В, Пальчик С.П. Розвиток виробничої організації на основі впровадження системи управління якістю та енергоефективних науковомістких технологій. Збірник наукових праць 7-ої міжнар. наук.-прак. конф. КЗЯТПС ЧПНУ, м. Чернигів, травень 2017 р. Чернігів, 2017. С. 102-104.

2. Калита П.Я. Головна ланка, або як витягнути ланцюг соціальноекономічних проблем (на прикладі України). Стандарти $i$ якість. 2010. № 1. C. 8-13. URL: http://www.efqm.org/the-efqm-excellencemodel95 (дата звернення: 20.09.2011).

3. Менеджмент якості в будівництві і геном ділової досконалості організації : монографія / В.І. Савенко, С.І. Доценко, С.П. Пальчик, П.Я. Калита та ін. ; за ред. В.І Савенка. Київ : Центр учбової літератури, 2018. $230 \mathrm{c}$.

4. Калита П.Я. Нарис про геном успішності організацій і держави. Частина 1. Стандартизаиія, сертифікаиія, якість. 2014. № 1. С. 33-38.

5. Богданов О.О. Тектологія. Загальна організаційна наука. Третє видання. Москва, 1929. 657 с.

6. Савенко B.I., Доценко С.I., Клюєва В.В., Пальчик С.П. Концептуальні засади ефективного розвитку будівельної організації на базі 
раціонального управління. Управління розвитком складних систем: збірник наукових праць. № 33. Київ : КНУБА, 2018. С. 123-129.

7. Дослідження i математичне моделювання організаційних структур та виробничих процесів будівельних організацій комбінатного типу : монографія / В.I. Савенко, С.I. Доценко, I.С. Нестеренко, П.М. Куліков та ін. ; за ред. В.І. Савенка. Київ : Центр учбової літератури, 2018. 124 с.

8. Мільнер Б.3. Теорія організації : підручник. Москва : Вища освіта, 2005. $646 \mathrm{c.}$

9. Савенко В.І., Доценко С.І., Пальчик С.П., Клюєва В.В., Терещук М.О. Інтелектуальні інформаційні інструменти розвитку виробничої системи енергетичного менеджменту та підприємства в цілому. Управління розвитком складних систем : збірник наукових праць. № 37. Київ : КНУБА, 2019. С. 195-204.

10. Научно-технические основы энергоэффективного экологически чистого электроотопления помещений, энергосбережение и энергоменеджмента: монография / І.В. Савенко, Н.М. Фіалко, С.І. Доценко, П.М. Куліков ; за ред. Н.М. Фіалко. Київ : Центр учбової літератури, 2018. 371c.

11.Брусан А.А., Черних Л.Ф. Теплоэффективные наружные ограждающие конструкции зданий. Перспективні напрямки проєктування житлових та громадських будівель. Київ : КиевЗНИИЭП, 2003. С. 65-74.

12. Фиалко Н.М., Черных Л.Ф. Тепловое состояние трехслойных наружных стен помещения при напольном электротеплоаккумуляционном отоплении Промышленная теплотехника. Приложение к журналу. 2004. Т. 26. № 5. С. 48-56.

13. Фиалко Н.М., Черных Л.Ф., Постоленко А.М. Влияние внутреннего каркаса здания на его тепловой режим. Оконные технологии. 2005. № 20-21. С. 44-47.

14. Богословский В.Н., Ферт А.Р., Черных Л.Ф. Экспериментальное подтверждение методики расчета наружных ограждающих конструкций. Теплоустойчивость наружных ограждающих конструкций зданий с учетом зависимости теплофизических характеристик от температуры. Bопросы повышения энергетической эффективности кондищионирования микроклимата. Москва : МИСИ им. В.В. Куйбышева, 1989. С. 10-14.

15. Савенко B.I., Сухоросов I.M., Полосенко О.В., Тарасов В.О., Фіалко Н.М. Енергозберігаючі технології в будівництві та система управління якістю. Будівельні матеріали, вироби та санітарна техніка. 2009. № 1 (31). С. 96-99. 
16. Новіков О.В. Основи функціональної теорії еволюції економічних систем. Питання економіки $i$ права. 2011. № 7. C. 141-144.

17. Савенко B.I., Доценко С.I., Клюєва В.В., Терещук М.O. Оптимальні методи управління будівельною організацією комбінатного типу. Управління розвитком складних систем : збірник наукових праць. № 35. Київ : КНУБА, 2019. С. 147-154.

18. Савенко В.І., Пальчик С.П., Клюєва В.В., Терещук М.О. Ентропія як прояв системної та діалектичної сутності будівельної організації комбінатного типу. Управління розвитком складних систем : збірник наукових праць. № 36. Київ : КНУБА, 2019. С. $142-147$.

19. Попов В.П, Крайнюченко І.В. Теорія і практика рішень : міждисциплінарний підручник. Саратов, 2018. 157c.

20. Шаповалова I.C. Соціогенетичний підхід у вивченні організаційної культури. Наукові відомості БелГУ. 2009. № 5. C. $159-167$.

\section{Information about the authors:}

Savenko V. I.,

Candidate of Technical Sciences $(\mathrm{PhD})$,

Doctor of Technical Sciences (RF), Doctor of Civil Engineering, Professor, Kyiv National University of Construction and Architecture 31, Povitroflotskyi ave., Kyiv, 03037, Ukraine

Kushchenko I. V., Candidate of Technical Sciences, Corresponding Member of ACU, Associate Professor,

Pryazovskyi State Technical University 7 Universytetska str., Mariupol, Donetsk region, 87555, Ukraine 